\title{
"OUR BENGAL MISSION": NEGOTIATION OF NATIONAL AND TRANSNATIONAL AGENDAS BY INTERWAR YUGOSLAV MISSIONARIES IN BENGAL
}

\author{
Helena $\mathrm{MOTOH}^{\prime}$
}

COBISS 1.01

\section{ABSTRACT \\ "Our Bengal Mission": Negotiation of National and Transnational Agendas by Interwar Yugoslav Missionaries in Bengal}

Contrary to the normative apostolic letter Maximum illud, which demanded that missionaries cut their ties with national(ist) and colonial agendas, the missionary project of the Yugoslav interwar missionaries in Bengal was deeply suffused with patriotism, with the newspapers and missionary publications alike portraying the Yugoslav Bengali mission as a symbolic victory of the newly-established Yugoslav state. The present paper aims to interpret this controversy by exploring how men and women missionaries negotiated the conflicting relationship between the transnational missionary project and the nationalist agendas, while also struggling with the controversial decisions of which national agenda to pursue.

KEY WORDS: missionaries, Bengal, Yugoslavia, patriotism, nation

\section{IZVLEČEK}

»Naš bengalski misijon«: Usklajevanje nacionalnih in transnacionalnih načrtov pri jugoslovanskih misijonarjih in misijonarkah v Bengaliji med obema vojnama V nasprotju z apostolskim pismom Maximum illud, ki je od misijonarjev zahtevalo, da pretrgajo vezi z nacional(istič)nimi in kolonialnimi interesi, je bil misijonarski podvig medvojnih jugoslovanskih misijonark in misijonarjev v Bengaliji globoko prežet s patriotizmom, tako časopisje kot misijonarski tiski pa so jugoslovanski bengalski misijon prikazovali kot simbolno zmago nove jugoslovanske države. Članek želi to protislovje interpretirati z raziskavo načinov, na katere so usklajevali konflikt med transnacionalnim misijonarskim projektom in nacionalističnimi programi, pri čemer so bili pogosto pred težavno odločitvijo, interesom katere nacije naj sledijo.

KLJUČNE BESEDE: misijonarji, Bengalija, Jugoslavija, patriotizem, nacija

$\mathrm{PhD}$ in Philosophy, Senior Research Fellow at Science and Research Centre Koper, Garibaldijeva 1, SI-6000 Koper/Capodistria; helena.motoh@zrs-kp.si 


\section{INTRODUCTION}

The cover of the February 1933 Bengalski misijonar [Bengal Missionary], a well-read supplement to the monthly Jesuit journal Glasnik srca Jezusovega [Sacred Heart of Jesus Journal], featured a telling photo of the 29-year-old Jesuit missionary Stanko Poderžaj, the then-editor of the supplement.' The meticulously staged portrait of him, wearing a white cassock and looking pensively into the distance, seems to visually sum up the entire framework of the Yugoslav missionary enterprise in India. Indeed, the journal leaves nothing to the imagination and the introductory piece opens with a detailed description of the photo. Referring to the special occasion of Poderžaj being ordained a priest, the description places the photo "in his study in Kurseong below the Himalayas" (ibid.). Kurseong was the location of St. Mary's Seminary, an important training and education hub for Jesuit missionaries in Bengal, where most of the Yugoslav missionaries received their education. Poderžaj was part of the second group of Yugoslav Jesuit missionaries who were sent to what was a part of the Belgian Jesuit province in India (see Kolar 1998: 154; Kokalj 1989: 23). The first were the Croatian missionaries Vizjak and Mesarić, who came to India in 1925 and Poderžaj followed suit at the end of 1929 together with two other Slovenian Jesuits, France Drobnič and Janez Udovč (ibid.). The first women missionaries to come to India from Yugoslavia were the Macedonian Albanian Theresa Bojaxhiu alongside the Slovenian Magdalena Kajnč in 1928 (Kokalj 1989: 291). They were followed by a number of other men and women religious, ${ }^{2}$ not only to Bengal, but also to other parts of India.

In the abovementioned photo, Poderžaj is portrayed as a new missionary priest, sitting at a table against the background of a bookshelf full of "books he studies", ${ }^{3}$ one of them casually open on the table, and another - "the Bible in the Bengali language" (ibid.) - in his hands. We are told that while holding this book "he reflects on how to spread the word of God to the innumerable souls awaiting him" (ibid.). The most fascinating part of the photo, however, is the decoration on the back wall. Three pictures are displayed, and three maps. Of the pictures - so we are told - two are portraits of the most famous early Slovenian missionaries, Friderik Baraga (1797-1868) and Ignacij Knoblehar (1819-1858). The former with his missionary work in North America and the latter with his pioneering explorations in the White Nile basin, are here interpreted as role models and predecessors in the lineage of Slovenian missionary history, "their work and life always a shining example" (ibid.) for Poderžaj. It should be noted that the lineage displayed is not, for example, geographical - he does not honour the "great" Indian missionaries before him. It also does not follow the lineage of the Jesuits, since

1 »Naslovna slika« Bengalski misijonar - Glasnik srca Jezusovega 1, 1933: 2, 5.

2 In the present paper the term "woman religious" is used in the case of women missionaries as an alternative to the commonly (mis)used term "nun", since the term women religious emphasizes their choice of the "outward" service of these women in the world as an alternative to the cloistered contemplative life of a nun. 


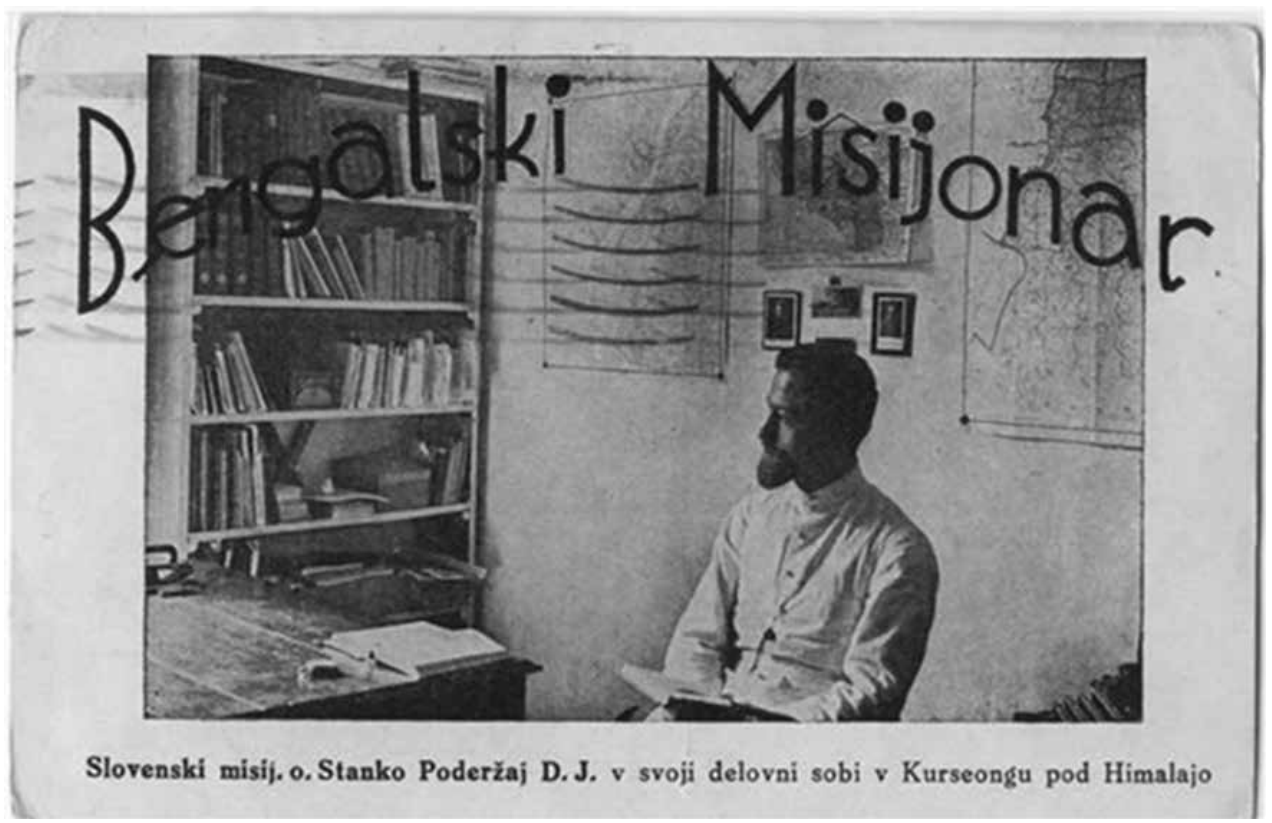

Figure 1: Cover of Bengal Missionary (February 1933).

neither Baraga nor Knoblehar belonged to the same religious order as Poderžaj. The lineage Poderžaj adheres to with his little improvised "altar" is a national one; what unites the two portraits with him is the fact that they spoke the same language, although it is debatable whether either of those two early-19 $9^{\text {th }}$-century missionaries would identify themselves as "Slovene". At the same time, of course, Poderžaj's homeland is also not "Slovenia" proper, since this political entity was then still over half a century away from formation. He did probably consider himself Slovene, however, even within the so-called "Kingdom of Serbs, Croats and Slovenes", which is what the political entity was called at the time of/just months before the publication. In October 1929, King Aleksandar I Karadjordjević, who had previously abolished the dysfunctional Yugoslav parliament and established a personal dictatorship, changed the name of the country to the "Kingdom of Yugoslavia". The change was not only nominal, for the aim of his politics was predominantly unitarian, aimed at a gradual blending of the three constitutive nations into a single Yugoslav nation. While Poderžaj, we are told in the article, "often thought about his homeland" and remained "in close contact with it" (ibid.), what this "homeland" was (or what it was called), was not clearly defined. Not only did the Kingdom of Serbs, Croats and Slovenes change its name merely a month before Poderžaj left home for India, but also the administrative unit governing his hometown changed entirely. King Alexander's reforms transformed the administrative units of the Kingdom of Yugoslavia, erasing any nominal and real ties between these units and the ethnic boundaries. Poderžaj's home region was now called the "Drava River province" ["Dravska banovina"]. Defined by a time when allegiances to 
political entities were therefore far from straightforward, one map on Poderžaj's wall, as if to pin down, or centre, the shifting political geographies, is given centre stage. Flanked by two maps of his missionary region in India, and just above Slovenian missionaries Baraga and Knoblehar, is a map of Yugoslavia.

The choice of the wall decoration is not as obvious as it might seem. Just a decade after the papal apostolic letter Maximum illud, which aimed at liberating the missionary project from any national, colonial or imperial ties, missionaries like Poderžaj were extremely limited in their expressions of patriotism. Or at least they were supposed to be. However, the reality, as this paper will show, was completely different for Catholic Yugoslav missionaries in India. Their whole undertaking was deeply suffused with patriotism and its changing faces and alliances, following the internal twists and turns in Yugoslav politics and the relations between the state and the Catholic Church.

In this paper, I will therefore address this problematic by analysing the specific case of Yugoslav men and women missionaries in order to explore how they negotiated the conflicting relationship between the transnational missionary project and the nationalist agendas. The main source for the analysis is the Slovenian press in the interwar period, both daily newspapers and missionary publications. Among the main Slovenian newspapers and journals, the developments in the Bengal mission were presented mostly in Slovenec, the daily newspaper published by the Slovenian People's Party (see Amon 1996: 88-94). The shifts of political allegiances of the Slovenian People's Party between the two World Wars are reflected in the changing attitudes towards the missionary project, as will be analysed in the paper. Other important sources of reports on the Bengal mission include various religious publications, most notably Bengal Missionary, mentioned above, published as a supplement of the monthly Jesuit publication Glasnik srca Jezusovega. The missionary enterprise crossed the boundaries of the religious orders, and the development of the Jesuit Bengal mission and the reports of the missionaries themselves also featured in Katoliški misijoni [Catholic Missions], a monthly journal published by the Congregation of the Mission since 1923 (see Kolar 1998: 184-190). Some reports about and by the missionaries can also be found in the publications of Slovenian religious orders and communities abroad, such as Ave Maria, a monthly journal of Slovenian Franciscan Missionaries in the USA. Since the number of articles especially in Slovenec and Bengalski misijonar allow for the most reliable comparison and analysis in the analysed period, these will be the main focus of the present paper. Since Croatian and Slovenian missionaries both took part in the Yugoslav Bengal mission, the same topic could be approached through the Croatian counterparts, both the daily press and religious publications, but due to the completely different political background of Croatian political life in Yugoslavia, this would require a separate study.

The complex relationship between the transnationalist standard set for the missionaries and the reality of growing nationalist pressure on them in the first half of the $20^{\text {th }}$ century has been analysed in more detail in Adrian Hastings' work (Hastings 
2003), but he mostly set the issue of the clash between nationalism and transnationalism against the background of Nazism and Fascism. Although in his other work (cf. Hastings 1997) the nationalisms of Yugoslav nations play an important role in his analysis, his writings on missionary nationalism do not reflect this. With the common background of the empires that fell in the early $20^{\text {th }}$ century, an interesting analysis was also made by Lehmann (2003), who focuses on German missionary nationalism and transnationalism in the interwar period. Due to the specific situation within the newly formed Yugoslav state and its multi-religious composition, none of those analyses can fully address the issue of the varied national and transnational agendas of the Yugoslav Catholic missionaries between the two World Wars. The relations which marked the nationalist and transnationalist agendas of the Catholic missionaries were not only those between the state and the Church, or the state and its changing international ambitions. In addition to these, the options that the Yugoslav Catholic Church was negotiating in its missionary attempts were also defined by the relations between three main religions in Yugoslavia, between Yugoslavia and the Vatican, and between the different political agendas of the constitutive nations and their political representatives. The ambiguities about what constituted a nation in the Yugoslav context also contributed significantly to the formation of missionary nationalism and transnationalism. Similarly, the issue of the complex position that women missionaries took on the nationalist and transnational agendas has also been researched (see Chaudhuri, Strobel 1992; Wildenthal 2001; Reeves-Ellington et al. 2009 etc.). Most of the analyses of nationalist positions of women missionaries, however, again focus on the experience of the greater nations and their established imperial agendas, where women were merely playing their role. The situation of the Yugoslav women missionaries, on the other hand, was different. The peripheral status of their country of origin marked their personal agendas in a way that their national identifications were greatly watered down by the complicated transnational paths they had to take to become missionaries in the first place, and additionally by the multi-national communities they became part of.

In the present paper I therefore try to look at the particular conditions that defined the national/transnational agendas of women and men missionaries in $\mathrm{Yu}$ goslav Bengal mission and to reflect on how their role was interpreted back home. In the first part I analyse the transnationalist turn outlined in Pope Benedict XV's Maximum illud. In the second part, I turn to an analysis of the openly patriotic and nationalist agendas of the interwar Yugoslav Catholic mission in Bengal. In the third part, I focus on the context of this patriotic orientation and on its likely causes in the changing(?) relationship between the state and the Catholic Church in Yugoslavia. Finally, I make a distinction between men and women missionaries in relation to the patriotic burden they were supposed to carry and the way they took on this task. This distinction will show that Yugoslav women missionaries inhabited what I refer to as a structural position, which enabled them to have more transnational 
allegiances than the strongly patriotic role which was expected of and assumed by the Yugoslav men missionaries.

\section{Against the Privatizing of the Vineyard}

Apart from the obvious expressions of homesickness, the missionary's allegiance to his homeland in the interwar period was problematized by the very top of the Catholic hierarchy. Unlike in the previous centuries when missionaries were considered helpful precursors, assistants or allies of the political agendas of their countries and empires, the period after the First World War saw a crisis of this type of alliances (see Hastings 2003). Most notably the crisis sprung from the conflicts with the staunchly national missionary structures devised by French missionaries in China, or even earlier, by the Padroado in the Portuguese colonies, which directly challenged the central authority of the Vatican. The close relationships between the national governments and their missionary outposts outside Europe presented risks at various levels, most often because the interests of the Church and the missionary activities had to be made subordinate to the political interests (ibid.: 16). The fact that the local populations were quick to observe the fact that missionaries had agendas other than just "saving souls" greatly reduced their credibility, and therefore hindered the success of the missionary project. And there were other reasons that made this link an unwelcome liability. In France, for example, the closeness between the missionary enterprise and state politics meant that the Church had to reckon with and negotiate the periodically stronger anticlerical sentiment which entered the highest level of politics (ibid.: 16-18). In order to address these issues and with a more visionary goal of surviving the turbulences stemming from the obviously immanent nationalist struggles arising in Europe as well as the decolonization processes outside the continent, an attempt to reform the overall missionary framework was urgently needed. It resulted in what is undoubtedly one of the most important "missionary" statements by a $20^{\text {th }}$ century pope, the 1919 apostolic letter of Pope Benedict XV, Maximum illud (see Pollard 2014: 114-116).

The views of the two highest Church authorities met in the shaping of this new orientation. The first was Pope Benedict $\mathrm{XV}$, a rather open-minded pope whose pontificate was marked by the horrors of the First World War and its aftermath. The other was Willem Marinus Van Rossum, the Dutch Prefect of the Congregation for the Propagation of the Faith, whose antinationalist orientation was crucial for the missionary policies of the upcoming new era (see Hastings 2003: 20). Facing harsh opposition in the missions and across Europe, Van Rossum also strongly advocated 
the advancement of local clergy to the episcopate, a vision that was to strongly mark the changes in the rest of the $20^{\text {th }}$-century Catholic missions. ${ }^{4}$

The papal apostolic letter starts by emphasizing the importance of missionary work as a direct fulfilment of Jesus' demand of his followers to "Go into the whole world and preach the gospel to all creation" (Benedict XV 1919) and continues with an overview of how Christianity was spread in and outside Europe by a list of missionaries, from Gregory the Illuminator to Francis Xavier (Benedict XV 1919: 4). Then he goes on to assess the size of the task left for the missionaries of his time: "According to a recent estimate, the number of non-believers in the world approximates one billion souls" (ibid.: 6). Comparing this to a statistical analysis Status of Global Mission (Status 2013), the Pope's estimate was fairly accurate, and the realistic numerical reference itself is something which gives a new tone to the missionary project.

The sheer dimensions of the task, continues the apostolic letter, call for a serious rethinking of how missionary activities are conducted and organized. In Maximum illud Benedict XV makes a distinction between the superiors and their subordinate missionaries. He addresses the former first, and demands of them devotion to their work and prudent governance of the missions and their subordinate missionaries, while also stressing the need for the network of missionary outposts to spread organically (Benedict XV 1919: 11). What is stressed here is that in the common project of bringing faith to the entire world, no area or task can be appropriated by one group only, as it is obviously better for missionaries to join forces should they want success: "If they find that their own order or congregation is not supplying enough manpower for the task, they are perfectly willing to call in helpers from other religious groups" (ibid.).

In an interesting shift, Benedict XV continues by heeding the over-zealous missionary superiors that the "Lord's vineyard" cannot be privatized: "On the other hand, We can hardly commend a man who takes the section of the Lord's vineyard that has been allotted to him for cultivation, and proceeds to treat it as a piece of private property, a domain not to be touched by the hands of an outsider" (ibid.: 12). Never should a superior refuse to seek help from others, he continues. Who are then these "others"?

He does not care who they are; he does not care whether they belong to his order or to another, or whether or not they are of his nationality [...] "And he does not limit his welcome to men, either. He will bring in sisters to open schools, orphanages, and hospitals, to found their hostels and establish other charitable institutions" (ibid.).

Not only were missionaries now supported by members of other congregations, other nationalities and (even!) women, but their main support lay in the future local

4 With the exception of a few missionaries, most notably Streicher in Uganda and Lebbe in China, the idea that the presence of European missionaries in the top layers of the local churches could, when sufficiently established, be completely replaced by local clergy (even at the episcopal level) was seen as dangerous and threatening to the inherited power relations in the colonies (see Hastings 2003; Mungello 2015). 
clergy, asserted Benedict XV. The vision of the transnationality of the Church is one of the main points of this papal letter: "The Catholic Church is not an intruder in any country; nor is she alien to any people. It is only right, then, that those who exercise her sacred ministry should come from every nation [...]" (ibid.: 14).

This idea is repeated in the part of the text dedicated to missionaries themselves. Reminding them that their primary task is that of saving souls, he refers to Psalm 44:11, from which he quotes: "Forget your people and your father's house" (Benedict XV 1919: 18). The duty of a missionary, he continues, is not to extend the human realm, but that of Christ, so that the citizens are acquired for the "heavenly fatherland, and not for an earthly one" (ibid.). The correct choice between these two fatherlands is an important marker of Benedict's missionary reform. If a missionary busied himself with obtaining prestige for his homeland, the local population would become suspicious of his real intentions, and justly so. Benedict XV seems to already envision the fall of the colonial world system, after which the only way for the Church not to collapse with it was to become transnational: "Such a situation could easily give rise to the conviction that the Christian religion is the national religion of some foreign people and that anyone converted to it is abandoning his loyalty to his own people and submitting to the pretensions and domination of a foreign power" (ibid.: 19). A missionary who does not follow these guidelines is not a missionary at all, he concludes, since "the true missionary is always aware that he is not working as an agent of his country, but as an ambassador of Christ" (ibid.: 20).

\section{A Promise of Glory for a Small Nation}

Established half a decade after Maximum illud, the Yugoslav mission in Bengal begins in contradiction. The very reason it was established was that the Belgian Jesuits, very much in line with the papal apostolic letter but not only for that reason, decided to invite help from other nations. Bengal had been entrusted to the Belgian Jesuits by Pius IX in 1859 (Kokalj 1989: 20), but it turned out to be increasingly difficult to sustain active missionary outposts over the whole area, mostly due to the lack of missionaries and financial difficulties (ibid.). When the situation in the missions generally worsened in the wake of the First World War, many outposts were abolished, while the Belgian mission began focusing its attention on the more successful missionary regions, such as Chota Nagpur Plateau (ibid.: 22). In 1924, the head of the Yugoslav Jesuit province, Father Anton Prešeren, made an agreement with the Belgian Provincial, Father Willaert, for Yugoslav missionaries to take over missionary tasks in the deserted areas of the 24 Parganas district in the Ganges delta (Kolar 1998: 154-155). This allegedly transnational gesture, however, contained a very "national" promise, namely, the Yugoslav missionaries were led to believe that in time, this would become their own missionary territory, a promise that was never fulfilled (Targa 2013: ix). For that reason, even before the departure of the Yugoslav missionaries, the news that they had been promised their own mission in Bengal greatly resonated in their 
homeland. In religious publications but also in other newspapers, it was interpreted as a great patriotic achievement for the new country, an understanding which stood in total opposition to the guidelines of the papal apostolic letter. Below I will analyse some of the potential causes for this explicit "disobedience", but first let us reconstruct the tones of this patriotic discourse.

Before the departure of the three missionaries from Slovenia in November 1929, the newspapers reported on their departure in pompous tones. In Slovenski list of 18 November 1929 we read of the farewell ceremony in Ljubljana, attended by two bishops and other high representatives of the Catholic Church. The crowds that wanted to attend the ceremony were supposedly so large, that - so the newspaper reports police had to intervene to keep at least a thousand people out of the ceremonial hall. The long ceremony was also decidedly politicized, even to the point that the ban's wife led the performance of a children's choir. The main speaker, cathedral priest Tomaž Klinar, stressed not only the religious, but also the political importance of the missionaries' brave undertaking: "Together with the Catholic faith our missionaries also carry our name far from our homeland. [...] When it gets its own missionary right, we will be listed among the great nations. How important this farewell and this journey are for our beloved Yugoslavia!" ${ }^{5}$

We find similar praises in various publications of the time. Interestingly, a lot of them seem oblivious about the exact status of the mission the Yugoslav Jesuits were sent to, and are quick to claim that the mission already belongs to Yugoslav Jesuits, although that was not the case:

For us Yugoslavs, this is a historical event. For the first time in history we are sending our missionaries to the overseas missions on our own, and not under the name of the Germans, French or Italians, as has been the practice to date. This is the establishment of our own Yugoslav missionary province where pagan culture is at its peak, in Bengal. ${ }^{6}$

As we can see, this "inaccuracy" did not only appear in the daily newspapers, where it could perhaps be attributed to the writers not being completely familiar with the details. The same rhetoric was used by missionaries themselves, most explicitly in the first issue of Bengal Missionary, in an article titled "Our Bengal mission":

Divine providence granted our Slovenian and Croatian missionaries of the Jesuit Society their first independent missionary region [...] This is now the first independent Yugoslav missionary land. It is ours and no other nation will take care of it anymore. It was entrusted to our missionaries $[\ldots]^{7}$

5 „Slovo naših misijonarjev«, Slovenski list, 18 November 1929: 3.

6 »ugoslovanski misijon v Indiji«, Slovenec, 27 October 1929: 8.

7 »Naš bengalski misijon«, Bengalski misijonar - Glasnik srca Jezusovega 1, 1933: 1, 2. 
The exaggerations do not stop here. For many different reasons, the details about the actual size of the missionary region allegedly "handed over" to Yugoslav missionaries were obfuscated. Most often the reader was led to believe that Yugoslav missionaries were entrusted with the entire Bengal region, and not only the 24 Parganas district. Supporting this misrepresentation, we find maps that mark a region much larger than the actual domain of the missionaries.

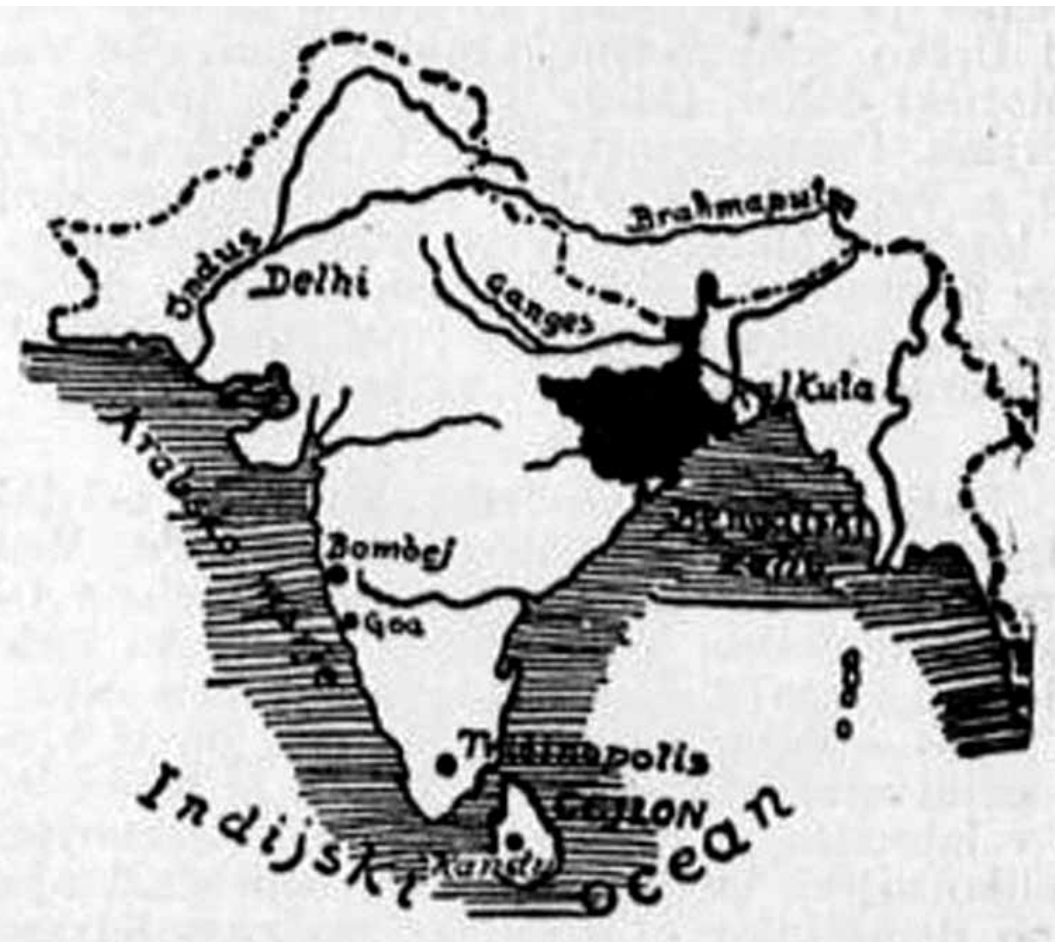

\section{Indija. Crno označeno je misijonsko ozemlje, kjer delujejo slovenski in hrvatski mistlonarji.}

Figure 2: Map of India showing the "Yugoslav mission". The text explains that the black colour indicates the region of Slovenian and Croatian missionaries

(source: „Slovensko misijonstvo«, Slovenec, 31 August 1930: 12).

While the ethnic and cultural unity of the nations in the newly established Yugoslavia (at the time still under the name "The Kingdom of Serbs, Croats and Slovenes") seemed hard to achieve, the group of Slovenian and Croatian missionaries were establishing, according to the press reports, "a religious and cultural outpost of Yugoslavianness in India". ${ }^{8}$ The difficulties and insecurities in forming the new

»Verska in kulturna postojanka Jugoslovanstva v Indiji«, Slovenec, 18 December 1927: 6. 


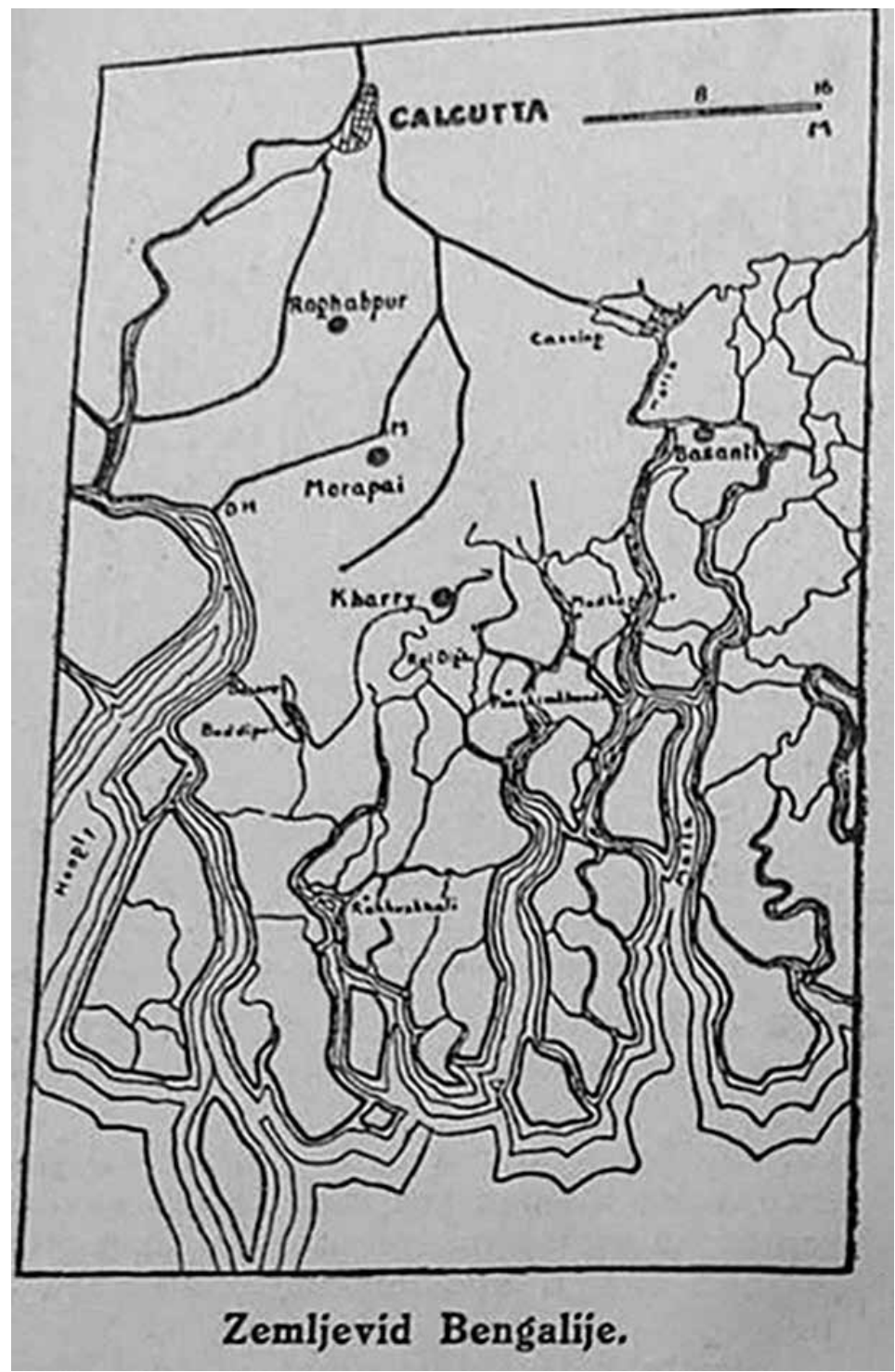

Figure 3: A much more realistic map of the 24 Parganas district where the Yugoslav missionaries were working (source: »Naš bengalski misijon«, Bengalski misijonar -

Glasnik srca Jezusovega 1, 1933: 1, 2) - however, it still says "Map of Bengal".

Yugoslav identity, however, were nevertheless evident in almost all of the articles published. The authors interchangeably labelled the missionaries and their mission as "Yugoslav", "Slovenian", or simply "Our", a confusion which is still present in later texts on the topic (see Kolar 1998: 154-155). Such a transposition also takes place in an interesting article on the "Yugoslav missionary outpost in India", where, despite the title, the text actually focuses on the dispositions of the Slovenian nation: 
They say that we Slovenes are few. But we live across the globe. Not as masters of large and rich colonies, but nevertheless as colonizers or conquistadors, "conquerors". [...] It is an honour for any nation if it has and provides for many missionaries [...]. Is not this then all the truer for us Slovenes, who are not a wealthy and big nation, but who in this difficult time are able to show the progress and successes of the missionaries abroad? ${ }^{9}$

The unitarian aspirations of King Alexander and the Belgrade government also divided Slovenian politics (see Perovšek: 2014). The liberals-centralists supported the forming of a new larger national identity in Yugoslavia, which they understood as a natural continuation of the development of the Southern Slavic ethnicities. At the same time, they claimed that the strength of this (larger) nation provided a possibility for national freedom (ibid.: 235-237). The proponents of the opposing position, the autonomists-federalists, were against the Yugoslav nation-building process and demanded more autonomy for the ethnic groups in Yugoslavia. The conservatives, especially the Slovenian People's Party of Anton Korošec, were strongly on the side of the latter group (ibid.: 237-239), although their positions changed considerably due to the daily political fluctuations. It is therefore quite contradictory that the missionaries, themselves proponents of the Catholic Church, ${ }^{10}$ would strive to represent themselves as working for the benefits of Yugoslavia and its national prestige, thereby going against both the official position of the Church and their political allies back home. As we will see in the following section, this unusual choice and the way it was shifting can only be understood against the backdrop of internal political developments in Yugoslavia and the changing relationship between the state and the Catholic Church.

\section{Negotiating the Relationship Between the Catholic Church, the State and the National Politics}

In order to understand how these unlikely alliances were formed, one has to go beyond the scope of the religious matters to the relation between the Church and the state in Yugoslavia. The numerous lapses and inconsistencies in the scope and meaning of "our" mission and "our" missionaries are an example of how these two levels substantially overlapped. As mentioned before, the new political formation, established after the First World War out of former parts of Austro-Hungarian Empire and the Kingdom of Serbia, struggled with the relation between the Yugoslav national identity and the national identity of the respective nations that comprised Yugoslavia. Apart from the three constitutive nations, Serbs (including Montenegrins) at 38.83\%, Croats at $23.77 \%$ and Slovenes at $8.53 \%$ of the population, there were several other

9 »Jugoslovanska misijonska postaja v Indiji«, Slovenec, 4 December 1932: 4.

10 Furthermore, one of the key figures of the missionary project between the two World Wars was Lambert Ehrlich, a well-known protagonist of an ultra-conservative faction called "the Catholic Right". 
nations (Bosnian Muslims, Macedonians etc.) which also played an important political role (Banac 1988: 58; see also Mithans 2017: 72). In addition, the new country now had to address the issues of religious plurality. The religious distinctions largely overlapped with ethnic distribution, especially between the two largest ethnic groups.

For Croats and Serbs, language differences could not be the determining criterion, given that their language had been commonly thought of as "Serbo-Croatian" since the end of the $19^{\text {th }}$ century. In the absence of linguistic difference, religion assumed the main role of the criterion of national identity, which tainted the structural characteristics of nations and nationalisms in Yugoslavia, especially in the interwar period (Mithans 2017: 28-30). The numbers of Catholics and Orthodox Christians were comparable; in 1921 46.6\% were Orthodox and 39.4\% were Catholic, while the Muslim population was $11.1 \%$ (ibid.: 72 ). In this context it is clear how religious identity could be used for political identification, but the forms of these politicizations still vary between the different national and political contexts. As Ratej claims in her paper on the politicization of the Catholic and the Orthodox Churches between two World Wars, the main controversy was the Serbian-Croatian conflict, which in turn politicized the antagonism between the Catholic and the Orthodox Church (Ratej 2008: 37). The alleged anti-Yugoslav position of the Catholic Church was a reflection of this politicization.

From the beginning, one of the problems of the relationship between the Catholic Church in Yugoslavia and the Yugoslav state was the absence of a singular legal standard determining this relationship. In 1918, many different agreements regulating the relationship between the Catholic Church and parts of the country were in place simultaneously: the Serbian concordat of 1914, the Convention with Montenegro of 1886, the Convention for Bosnia and Herzegovina of 1881, and several Austrian and Hungarian laws in those parts that belonged to the Austro-Hungarian Empire (Mithans 2017: 81-82). Already in 1918, at the Episcopal conference of the Catholic Church in Yugoslavia, it was proposed that this issue be uniformly resolved in a concordat between the Vatican and the new kingdom. For the Vatican, especially between the two World Wars, concordats were the preferred method of solving the issues of the status of Catholic Church in individual countries (ibid.). In 1922 the Yugoslav government agreed to this option and the negotiations commenced.

The history of the negotiations on the Yugoslav concordat is extremely complex, and the reasons why each of the sides was interested at all in making this agreement are equally diverse. On the side of the Church, the interest in securing a stable position in this unpredictable multinational union, where the competing Serbian Orthodox Church had a strong influence, played a major role as a potential guarantee for the future. To obtain this, the Church was ready to accept some radical compromises, for example, allowing the Old Slavic and Glagolitic scripts to be used in Catholic liturgy (ibid.: 106). The state's agenda was also complex. Securing a stable agreement with the Vatican would firstly enable them to bypass repeated negotiations with Catholic bishops in Croatia and Slovenia. Secondly, this agreement would 
acknowledge the position of the two constitutive Catholic nations in Yugoslavia and hopefully silence their dissent on a national basis. As Charles Loiseau, the advisor to Yugoslav King Alexander, reportedly claimed (ibid.: 90), a concordat would separate the Catholic sentiment from the Croatian sentiment and prevent the nationalisms growing stronger with the help of religious affiliations. This de-nationalization of the Church, however, at the same time also meant a "nationalization" of the Church, by which of course we now mean Yugoslavization. With the permission to use Old Slavic and Glagolitic script and with plans to establish a unified "Yugoslav Catholic Church" (ibid.), the state would gain increased control over one of its biggest potential opponents.

Despite the long negotiations and the final failure of the concordat, ${ }^{11}$ the complex developments related to it can help us understand the mixed allegiances expressed by the Slovenian missionaries of the Bengal mission and the newspaper representations of them. The attempt to "Yugoslavize" the Catholic Church and the different levels of opposition to this process explain the evident desire to portray the new Bengal mission in the light of this ideological twist. Furthermore, the years when this "missionary patriotism" was most explicitly expressed in publications also overlap with the restart of negotiations in the wake of King Alexander's dictatorship, and lasted approximately until the first year after his death in 1934, when critics of the agreement started delaying its acceptance by the parliament. Another interesting factor has to be taken into account, this one on the level of Slovenian politics within Yugoslavia. The main conservative political party, the Slovenian People's Party, which was closely connected with the Church, spent the period between the forming of the Kingdom of Serbs, Croats and Slovenes and the dissolution of the Kingdom of Yugoslavia shifting political alliances. Being initially strong supporters of the forming of the Yugoslav kingdom in 1918, they effectively went from defending the autonomy and sovereignty of the Slovenian nation in the Austro-Hungarian context to becoming supporters of the new increasingly unified state. After failing to win in the 1920 elections and becoming an opposition party, they once again shifted to a more federalist/autonomist position, only to go back to a centralist position after re-joining the government in 1927. The crisis after the parliamentary shooting in 1928 and the subsequent dictatorship of King Alexander Karadjordjević put the

11 The negotiations were neither smooth nor fast. After the initial start in 1925, some disagreements led to a standstill which lasted for four years. In 1928, one of the biggest opponents of the concordat, the Croatian nationalist Stjepan Radić, was assassinated in the parliament, an incident which led to the dissolution of the parliament and the self-proclaimed dictatorship of King Alexander. In this increasingly unitarian political climate in the now renamed and reorganized Kingdom of Yugoslavia, the negotiations picked up in 1931 and then continued in secret from 1933 to 1935 through king's special envoy, Nikola Moscatello. Although the successfully negotiated concordat was then signed in June 1935, its critics caused delays before it was brought to parliamentary vote. Even that was not enough for the agreement to be finally accepted and - after waiting for almost another year - Prime Minister Stojadinović finally announced his decision in February 1938 that the concordat would not be brought before the senate for a final vote (see Mithans 2017: 118-166, 219-271; Ratej 2008). 
Slovenian People's Party along with many other political parties in Yugoslavia under a strict ban and brought its leaders into confinement. In order to recover its position after the King was assassinated and the ban was partly lifted, the SPP joined with two conservative parties of Bosnia and Serbia to form the Yugoslav Radical Union, while this new party was then constantly negotiating between the explicit unitarianism of their structure and the implicit particularism of the constituent three national parties. These shifts must have at least partially informed the Church's and the media's positions on the missionaries' patriotic duties, and can help explain the seemingly confusing shifts in terminological choices between "Slovenian" and "Yugoslav" as synonyms for "our(s)" in the texts on the missionary project in Bengal.

\section{National Men and Transnational Women}

There was, however, another internal distinction within the missions themselves. In the expressions of missionary nationalism in publications and newspapers, the protagonists were mostly "our" male missionaries, mostly Jesuits (with a few representative Salesians thrown in). Only very sporadically do we find references to women missionaries and their role in the Bengal mission in particular. The task of representing their nation was universally ascribed to male missionaries and virtually never to women. Needless to say, none of the missionary women religious received a farewell ceremony of the type that was organized for Poderžaj, Drobnič and Udovč, although two of them, Magdalena Kajnč and Theresa Bojaxhiu (later known as Mother Theresa) had departed for India a year earlier than the three Jesuits. ${ }^{12}$ With the exception of texts by Mirjam Zalaznik, a PhD educated Loreto sister, and a few occasional letters from other women missionaries, they also did not have a voice in the otherwise abundant missionary press of the time.

This misrepresentation does not do justice to the role which women missionaries played in the missions. The tasks for the missionaries in Bengal were manifold. Apart from doing missionary work and caring for the souls of the local population, they also provided medical assistance, tended to the poor, tried to introduce agricultural and technological innovations and even organized social help such as rice foundations to help the impoverished population of the 24 Parganas district to get over the worst years (see Bengalski misijonar). These tasks were divided among men and women missionaries fairly equally, and the small groups of men and women religious also shared the missionary outposts without an obvious hierarchy between them. In the absence of personal accounts, it is of course difficult to speculate on what equalities or inequalities were present among men and women religious in Bengal mission of the time, but it can be assessed that that their responsibilities - if not their status - seem in many ways comparable.

12 There was only a short note on their departure in »Nova slovenska misijonarka«, Katoliški misijoni, 1928/29: 3). 
We could of course speculate in large theoretical frameworks about how the patriotism in missionary contexts simply adopted the patrilineality of the society in general, where the sons represent the family, and the daughters belong to the family of their husbands, in this case the Church. A tone like this can for example be discerned in a text by Antun Vizjak, a Croatian Jesuit missionary in Bengal. He tells a story about two women missionaries suffering an attack by savage bandits, and comments: "The women missionaries in pagan lands sacrificed their beloved father's home, they sacrificed their homeland with all its joys, and finally they even sacrifice their life - all for Jesus, for the salvation of the souls". ${ }^{13}$

On the other hand, the transnationality that is here ascribed to women is precisely the standard that - according to Pope Benedict XV - all missionaries were supposed to follow, regardless of their gender. But it must be noted that the transnationality for women missionaries was not necessarily one of choice, and should not automatically be ascribed to their more "awakened" missionary sense. Various factors were in play. If we simply analyse the list of Slovenian missionaries that served in India in the $20^{\text {th }}$ century, we can immediately see a drastic difference. Among all of 13 Slovenian men missionaries in India before the Second World War, only three served outside of Bengal (see Kokalj 1989: 287-302). For women, on the other hand, the ratio was different - only half were part of the Bengal mission and others were doing missionary work in other parts of India, ranging from the south to the northeast. That alone, together with the stress that was placed on the patriotic importance of the Bengal mission, could explain why women missionaries were less entangled in the nationalist discourse.

Even more importantly, if we compare the men and women missionaries in Bengal itself, we notice another dissimilarity. Although their paths eventually met in the missionary outposts of Basanti, Morapai and other places, how they got there differed greatly. With two exceptions (i.e. the Salesians), all of the missionaries of the Bengal mission were Jesuits, and the career path they had to take to end up in India was fairly predictable. The main steps in their trajectory were either the St. Andraž Jesuit community in Austrian Carinthia, the Jesuit seminary in Pullach near Munich and/or the Jesuit College in Travnik in Bosnia (ibid.). Throughout all these stages they remained in close connection with institutions back home and with their compatriots on the way. Women missionaries, on the other hand, belonged to a number of different religious congregations: the Daughters of the Holy Cross, the Medical Mission Sisters, the Loreto Sisters, FMA Daughters of Mary Help of Christians, the Carmelites and the Franciscan Missionaries of Mary (ibid.). Accordingly, the stations on their path to the Bengal mission were individual, going through places as diverse as Belgium, England, Ireland, Italy, Spain, and Germany (ibid.). When they finally came to India, they belonged to communities within which they were often 
the only "representatives" of Yugoslav nationality. Transnationality in their case was a condition of their religious life and not necessarily an option they would choose.

\section{The Case of the Yugoslav Bengal Mission}

Before long, the patriotic zeal of the Bengal mission was numbed by the harsh realities of the 1930s, and the optimistic patriotism of the early years turned into a patriotism of need. Most of the time, Bengal Missionary reported on the hardships, famine ${ }^{14}$ and natural disasters that struck the 24 Parganas district, putting noticeably more effort into convincing their compatriots in Slovenia to help with donations. At the same time, Europe was suffering its own problems. Nazism and fascism were growing stronger, and in Yugoslavia the nationalist-religious oppositions managed to completely stop the process of creating the Yugoslav concordat. Along with the gradual failure of the nation-building process of a potentially unified Yugoslav nation, the patriotic optimism of the early years of the Bengal mission soon became a thing of the past. The emphasis was now rather placed on the "Slovenian" and "Croatian" identity of the Bengal missionaries, and the links between the missionaries and their homeland were not so much of national pride, but became lifelines which kept their missions and sometimes even the missionaries themselves from dying.

The beginning of the Second World War also brought the end to the publication of Bengal Missionary, which had played a major role in representing missionary work in India to Slovenian readers for almost a decade. In one of the last issues, in January 1940, the supplement published a letter by Ferdinand Perier, the Archbishop of Calcutta. ${ }^{15}$ The letter sums up well what the idealistic missionary patriotism of the late 1920s transformed into under the economic and political pressures of the 1930s. The title of the article presenting his letter is "A great expression of gratitude to our nation" (ibid.). Although the reference to "our nation" is again unclear, it can be discerned from Perier's text. The letter of gratitude, it turns out, is in fact a request and a plea to "Slovenian and Croatian Catholics" to donate to the building of the Church of St. Theresa in Basanti. Furthermore, the archbishop expressed his hopes that the faithful donors do not take the donations for the church away from the sum they would otherwise give for the missionary outposts, effectively asking them to give an additional sum. With a hint of what almost sounds like historical irony, he adds: "since it is much more important and urgent to build temples of God in the souls" (ibid.).

Within a decade and a half of the existence of the "Yugoslav" Bengal mission, it became a laboratory for a specific historical intertwinement of the heterogeneous

14 According to Paul Saumik's report "1930-1943: Agrarian Transformation and the Famine in Bengal", the 1930s present a structural paradigm that later led to the catastrophic 1943 Bengali Famine (https://hermes-ir.lib.hit-u.ac.jp/rs/bitstream/10086/28239/1/wp2016-11.pdf). We can only speculate from the missionary reports that the impoverished and inhospitable areas in the Ganges delta were the first to experience the adverse effects of these structural changes. 
motivations of the religious missionary zeal and the political aspirations of a newly formed nation. In addition, the representations of this mission also reflected the many shifting national and political identities and allegiances within Yugoslavia. This particular context, which I have analysed in the present paper, made the case of the Yugoslav Bengal mission and its women and men missionaries unique. A comparison with similar cases of smaller or multi-ethnic national missions might show whether the same trends could be discerned in other missions in India and elsewhere. At the same time, this particular missionary case was part of the larger shifts of the time, the negotiating positions on the role of the Church in the European nationalisms of the time, and the bigger picture of a decolonizing world and, consequently, localized Church structures and a transnational Church.

\section{REFERENCES}

Amon, Smilja (1996). Tisk in politika v Jugoslaviji (1918-1941). Ljubljana: FDV.

Banac, Ivo (1988). The National Question in Yugoslavia: Origins, History, Politics. Ithaca, London: Cornell University Press.

Benedict XV (1919). Maximum illud. http://www.svdcuria.org/public/mission/docs/encycl/mi-en.htm (10. 2. 2019).

Chaudhuri, Nupur, Strobel, Margaret (1992). Western Women and Imperialism: Complicity and Resistance. Bloomington and Indianapolis: Indiana University Press, 1992.

Hastings, Adrian (2003). The Clash of Nationalism and Universalism within Twentieth-Century Missionary Christianity. Missions, Nationalism and the End of Empire (ed. Brian Stanley). Grand Rapids, Michigan/Cambridge; UK: William B. Eerdmans Publishing Company, 15-33.

Hastings, Adrian (1996). The Construction of Nationhood: Ethnicity, Religion and Nationalism. Cambridge: Cambridge University Press.

Kokalj, Jože (1989). Pogovori ob Gangesu. Ljubljana: Župnijski urad Dravlje.

Kolar, Bogdan (1998). Na misijonskih brazdah cerkve. Celje: Mohorjeva družba.

Lehnamm, Hartmut (2003). Missionaries without Empire: German Protestant Missionary Efforts in the Interwar Period (1919-1939). Missions, Nationalism and the End of Empire (ed. Brian Stanley). Grand Rapids, Michigan/Cambridge; UK: William B. Eerdmans Publishing Company, 34-53.

Mithans, Gašper (2017). Jugoslovanski konkordat: Pacem in discordia ali jugoslovanski »kulturkampfu. Ljubljana: Inštitut za novejšo zgodovino.

Mungello, D. E. (2015). The Catholic Invasion of China: Remaking Chinese Christianity. Lanham, Boulder. New York, London: Rowman \& Littlefield.

Perovšek, Jurij (2014). Vprašanje domoljubja na Slovenskem v času Kraljevine Srbov, Hrvatov in Slovencev/Jugoslavije 1918-1941. Prispevki za novejšo zgodovino 1, 231-243. 
Pirjevec, Jože (1995). Jugoslavija: [1918-1992]: Nastanek, razvoj ter razpad Karadjordjevićeve in Titove Jugoslavije. Koper: Lipa.

Pollard, John (2014). The Papacy in the Age of Totalitarianism, 1914-1958. Oxford: OUP. Ratej, Mateja (2008). Odtenki politizacije Rimskokatoliške in Srbske pravoslavne cerkve pri Slovenski ljudski in Narodni radikalni stranki med svetovnima vojnama. Prispevki za novejšo zgodovino XLVIII/2, 35-52.

Reeves Ellington, Barbara, Sklar, Kathryn Kish, Shemo, Connie A. (2009). Competing Kingdoms: Women, Mission, Nation, and the American Protestant Empire, 18121960. Durham, London: Duke University Press.

Status of Global Mission, http://christianityinview.com/downloads/StatusOfGlobalMission.pdf (5. 2. 2019).

Targa, Sergio (2013). Satkhira: The Diaries of the Jesuit Fathers (1918-1947). Osaka: Asian Study Centre.

Wildenthal, Lora (2001). German Women for Empire, 1884-1945. Durham, London: Duke University Press, 2001.

\section{NEWSPAPERS SOURCES}

Ave Maria, 1932

Bengalski misijon - Glasnik srca Jezusovega, 1933, 1940

Katoliški misijoni, 1928/29

Slovenec, 1927, 1929, 1930, 1932

Slovenski list, 1929 


\section{POVZETEK}

\section{„NAŠ BENGALSKI MISIJON«: USKLAJEVANJE NACIONALNIH IN TRANSNACIONALNIH NAČRTOV PRI JUGOSLOVANSKIH MISIJONARJIH IN MISIJONARKAH V BENGALIJI MED OBEMA VOJNAMA Helena MOTOH}

V nasprotju z apostolskim pismom Maximum illud, ki je od misijonarjev zahtevalo, da pretrgajo vezi z nacional(istič)nimi in s kolonialnimi interesi, je bil misijonarski podvig medvojnih jugoslovanskih misijonark in misijonarjev v Bengaliji globoko prežet s patriotizmom, tako časopisje kot misijonarski tiski pa so jugoslovanski bengalski misijon prikazovali kot simbolno zmago nove jugoslovanske države. Članek to protislovje interpretira z raziskavo načinov, na katere so usklajevali konflikt med transnacionalnim misijonarskim projektom in nacionalističnimi programi, pri čemer so bili pogosto pred težavno odločitvijo, interesom katere nacije naj pravzaprav sledijo.

Prvi del članka je posvečen transnacionalističnemu obratu, ki ga je v doktrino in prakso misijonarstva po svetu zarisalo apostolsko pismo papeža Benedikta XV., Maximum illud. V drugem delu sledi analiza prav nasprotnega pojava, odkrito patriotskih in nacionalističnih načrtov medvojnega jugoslovanskega katoliškega misijona v Bengaliji. V tretjem delu se članek posveča kontekstu te specifične domoljubne usmeritve in vzroke zanjo išče v spreminjajočem se odnosu med (jugoslovansko) državo in Katoliško cerkvijo. Na koncu članek vzpostavi še ločnico med misijonarji in misijonarkami glede na patriotsko breme, ki so ga morali nositi, in glede na to, kako so to nalogo sprejeli. Ta ločnica pokaže, da je jugoslovanskim misijonarkam poseben strukturni položaj, v katerem so se znašle, omogočal, da so udejanjale bolj transnacionalne zaveze kot njihovi moški kolegi, od katerih se je pričakovala strogo začrtana domoljubna vloga. 